\title{
Assessment of intake of macronutrients of Punjabi women
}

\author{
Vibhuti Arya and Vinita Singh
}

Punjabi cuisine is one of the most distinct and popular Indian cuisine and comes from the region of Punjab situated partially in India and Pakistan. It offers a vast variety of delectable and exotic vegetarian and non-vegetarian dishes that are prepared with varied traditional culinary styles, particularly the tandoori style. The exotic and appetizing tandoor items and various other mouth- watering and finger licking dishes having rich, spicy and buttery flavour savoured with Punjabi Basmati rice of varied forms and special Punjabi breads like Tandoori roti and Naan have not only made made the gastronomists crave for more but has also garnered the cuisine much fame outside the Punjab region taking it to places around the globe like Canada and the UK. Present investigation was carried out in various areas of Kanpur. The following areas were selected for the survey such as Gumti, Govind Nagar, Ashok Nagar, Lajpat Nagar, Lalbangla. 100 Punjabi women were selected randomly for the study. The anthropometric assessment was done by taking height, weight and body mass index of the respondents. The mean nutrient intake was computed by the 24 recall method. The nutritional awareness level and food habit among the Punjabi women was assessed through the questionnaire. The maximum 15.15 per cent deficient energy was found in 35 to 45 years of age group and 8.43 per cent deficient energy was found in 45 to 55 years of age group. The maximum 18.18 per cent increase protein was found in 45 to 55 years of age group and 8.72 per cent increase protein was found in 35 to 45 years of age group. The maximum 134.0 per cent increase fat was found in 45 to 55 years of age group and 133.2 per cent increase fat was found in 35 to 45 years of age group.

Key Words : Assessment, Energy, Protein, Fat

How to cite this article : Arya, Vibhuti and Singh, Vinita (2019). Assessment of intake of macronutrients of Punjabi women. Food Sci. Res. J., 10(1): 81-83, DOI : 10.15740/HAS/FSRJ/10.1/81-83. Copyright@ 2019: Hind Agri-Horticultural Society. 